症例

\title{
新生児特発性胃破裂の 1 治験例
}

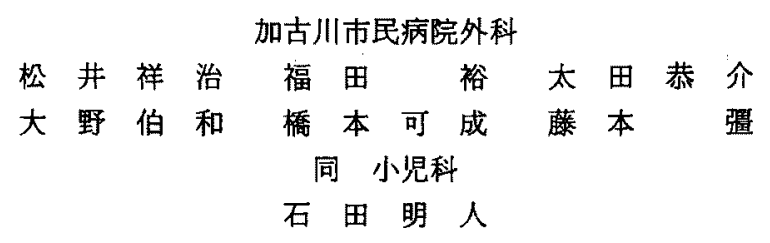

生後 5 日目の男子で特発性胃破裂を起こした症例に対して胃縫合術，腹腔ドレナージ 術等の婜急手術を施行した。腹水お上び血中より E. coliが検出され沉発性腹膜炎; 敗血 症併発と診断されたが集中的な術後管理に上って救命し得た，術後13日目に右精索，辠

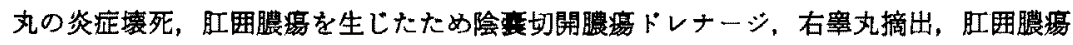
切開排膿術を施行して治瘜せしめた。

秉引用語：新生児特発性胃破裂

\section{緒 贯}

新生児特発性胃破裂の治療成綪注年々向上しつつあ るが，未だ充分でなく，ことに沉発性腹膜炎，敗血症 を併発した症例の数命率は今な拈低い,122). 今回私達は 沉発性腹膜炎，敗血症を併発した症例江胃楎合術，腹 腔ドレナージ術を施行し救命し得たものの術後13日目

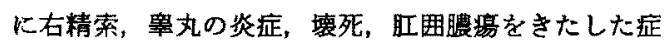
例を程験したので文嗝的考察を加えて報告する。

$$
\text { 症 例 }
$$

患者：生啳 5 日，男児.

主訴：腹部喑満, 呼睖困難, 黄庭。

家族歴：特記すべき事なし。

現病歴：父親40歳，母親38歳の第 1 子で好娠39週目 に正常分婏にて出生した. 生下時体重 $3,480 \mathrm{~g}$ で出生後 5ー6時間頃より授乳開始したが嘔吐はなかった．生 後 3 日目頃より腹部膨満が出現し 5 日目には腹部鲴満 の増強により呼吸困難を呈してきたため当院小児科 Newborn Intensive Care Unit (以下 NICU と略す) に紹介入院となった。

入院時現症および検查所見(表 1)：腹部の著明な膨 満が見られ，腸雑音の聴取は不可であった。体温は $37.8^{\circ} \mathrm{C}$ ，血压は $70 / 37$, 呼吸数 54 回/分，脈拍数 180 回/ 分で tachy cardia, tachy pneaが見られた。白血球数 は5,400/ $\mathrm{mm}^{3}$ と增加は見られなかったが, Ht $54.6 \%$

1991年7月16日受付 1992年 1 月17日採用

\section{表 1 入院時検查結果}

\begin{tabular}{|c|c|}
\hline \multicolumn{2}{|l|}{ 血液一般 } \\
\hline WBC & $5400 / \mathrm{mm}^{3}$ \\
\hline $\mathrm{RBC}$ & 496 万 $/ \mathrm{mm}^{3}$ \\
\hline $\mathrm{Hb}$ & $17.8 \mathrm{~g} / \mathrm{dl}$ \\
\hline $\mathrm{Ht}$ & $54.6 \%$ \\
\hline \multicolumn{2}{|l|}{ 生化学㭘查 } \\
\hline GOT & $56 \mathrm{KarU}$ \\
\hline GPT & $3 \mathrm{KarU}$ \\
\hline T.B. & $12.8 \mathrm{mg} / \mathrm{dl}$ \\
\hline $\mathrm{Na}$ & $133 \mathrm{mEq} / \mathrm{l}$ \\
\hline $\mathbf{K}$ & $5.3 \mathrm{mEq} / 1$ \\
\hline $\mathrm{Cl}$ & $103 \mathrm{mEq} / \mathrm{l}$ \\
\hline B.S. & $141 \mathrm{mg} / \mathrm{dl}$ \\
\hline \multicolumn{2}{|c|}{ 血激ガス ( $\mathrm{FiO}_{2}$ room air $)$} \\
\hline PH & 7.286 \\
\hline $\mathrm{PaO}_{2}$ & $72.8 \mathrm{mmHg}$ \\
\hline $\mathrm{PaCO}_{2}$ & $29.3 \mathrm{mmHg}$ \\
\hline$B E$ & -11.5 \\
\hline
\end{tabular}

と脱水㑯向を認めた。動脈血ガス分析は $\mathrm{PaO}_{2} 72.8$ $\mathrm{mmHg}, \mathrm{PcO}_{2} 29.3 \mathrm{mmHg}, \mathrm{pH} 7.286, \mathrm{BE}-11.5 \tau$ 軽度の低酸素血症と高度な Acidosisを呈した。循環動 態の改善目的で充分量の榆液, フルブミン製郕，ドー ハミン製剂の投与を行い利尿を得た. Acidosisはメイ ロンにて補正した。立位胸腹部単純写真では両側横隔 膜下に多量の free air 詝留像之腹腔内の鏡面像が認め られた(图 1)，18Gエラスター針による腹腔穿刺にて 


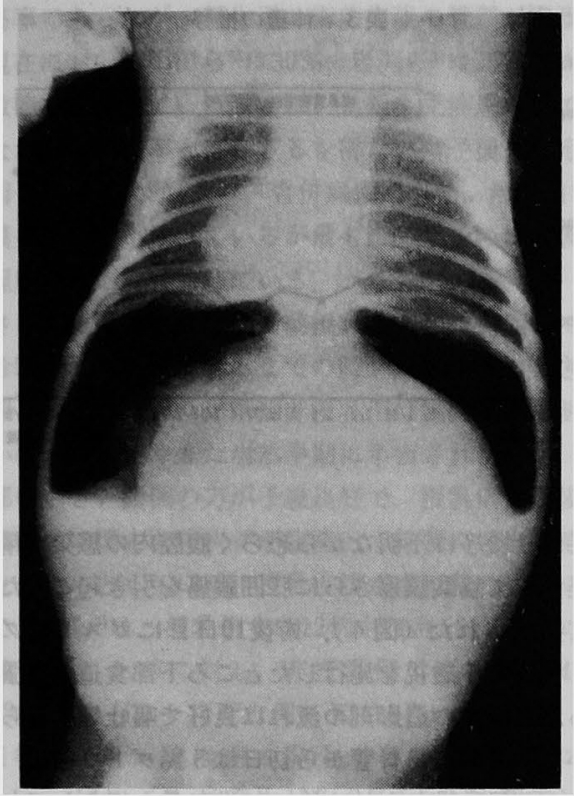

图 1 胸腹部立位単純 $\mathbf{X}$ 線

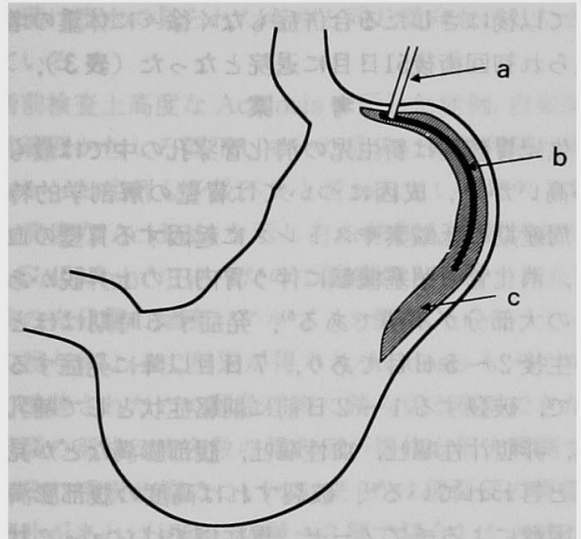

图2 破裂した胃のシェーマ：a）胃チューブ，b）破 裂部，c）漿膜・筋層断裂部

140ccの air と3ccのミルク様膿计を吸引した. そこで 上部消化管とくに胃破裂を薙い緊急開腹術に踏み切っ た.

手術所見：全身麻䣲下に上腹部正中切開にて開腹し た. 腹腔内には術前领んだと思われる大量のミルク様 㩨汁が存在し所々に膿苔の付着が見られた．胃大筫側 の漿膜，筋層が噴門值下より胃体中部まで約 $6 \mathrm{~cm}$ にわ たって断裂しており，さらにその中央部の粘膜が約3

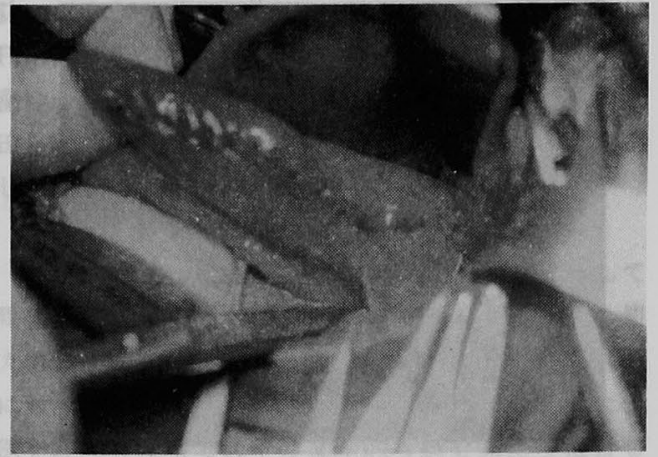

図 3 胃破裂部䋖合閉鎖終了時の術中写真

表 2 白血球数の推移

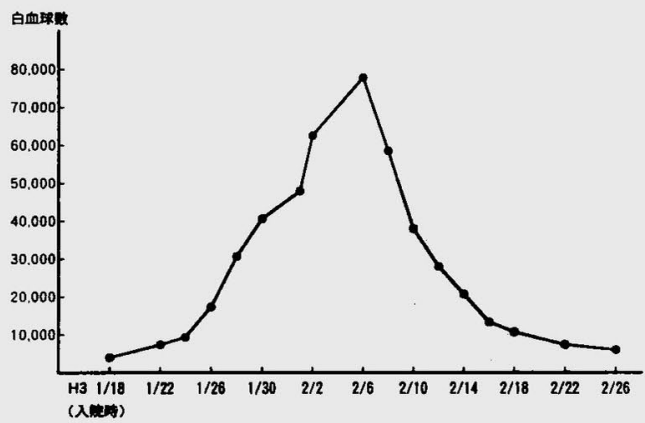

cmにわたって破裂していた，その粘膜破裂部の上端 より術前挿入されていた胃チューブが腹腔内に突出し ていた。 また獎膜, 管層断裂部の周辺が約 $1 \mathrm{~cm}$ の幅で 血尰を形成していた(図 2 ). 創面の Débridement は行 わずに, 4-0 Dexon 系による3層䋖合で閉鎖した(図 3 ). 腹腔内は大量の生食水にて充分に洗浄後, 両側横 隔膜下，胃壁絴合部，ダグラス窝にドレーンを挿入し て手術を終了した. なお腹腔内を検索するす他の消化 管の閉塞, 奇形等の異常は認められなかった.

術後経過：術後はそのままレスピレーターで乎吸管 理を行い，4 日目に抜管できた，術後もショック状態 からの離脱は容易ではなく引き続き適切な輸夜㞠法, フルブミン製剤，ドーハミン製剂の投与を行った。術 中の腹水細菌培養で E. coli と S. Aureus, 術後の動脈 血培養でも， E. coli が検出され敗血症と診断された。 白血球は最高 $79,600 / \mathrm{mm}^{3}$, CRP b 33.9 まで上昇した が，感受性のある抗生阂の併用投与，クロプリン製剤 の投与によって次第に回復が見られた(表 2 ). 術後 13 日目に右鼠径部, 右陰変の著明な腫脹, 肛囲の発赤が 


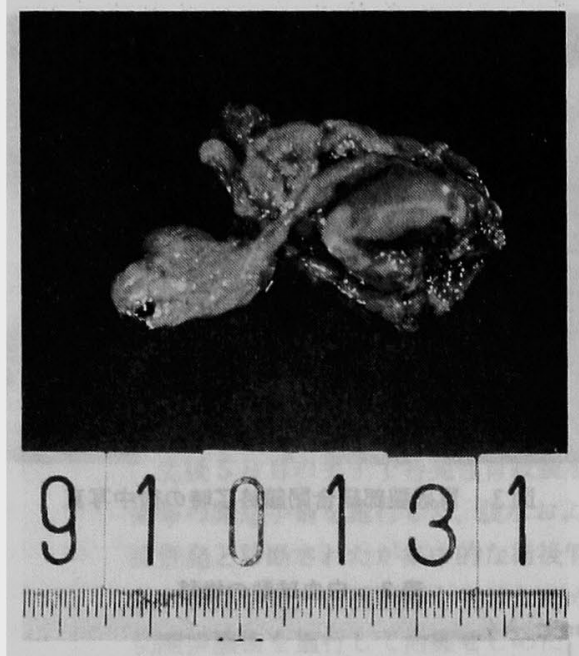

図4 摘出した右精索の一部と亳丸（壊死を起こして (る)

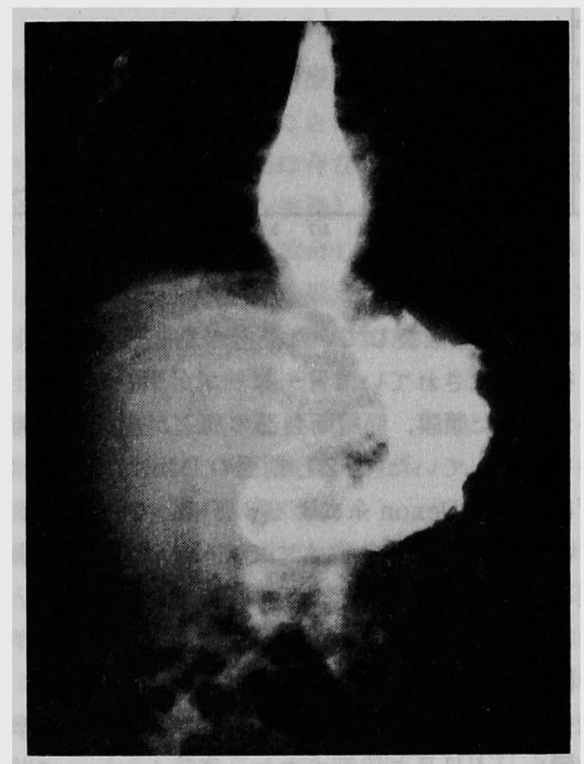

图 5 術後10日目のガストロクララィンによる上部消 化管透視

見られたので全麻下に再手術を施行した。陰变切開排 膿したところ, E. coli 臭の朖汁が多量に排出された。 右精索は著明に炎症性肥厚をきたしており受丸は完全 に壊死に樎っていたために摘出した。 肛囲膿瘍に対し ても切開排膿を行った。精索，陰变，肛囲膿㕫は連続

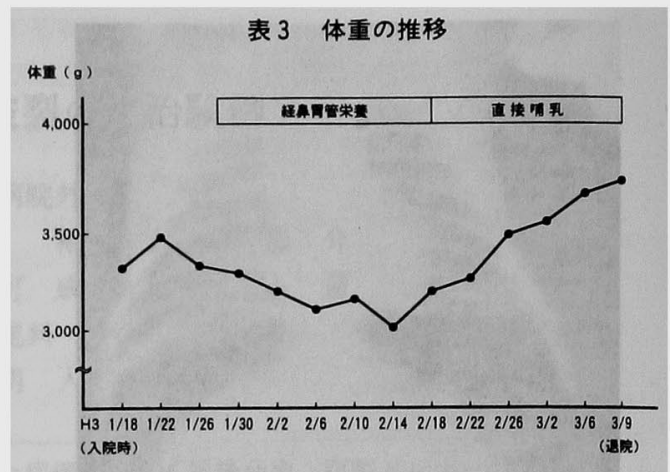

しており機序は不明ながら恐らく腹腔内の感染が精索

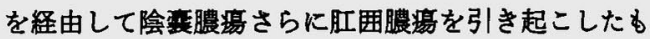
のと推察された（図 4 ）。術後10日目にガストロクラ フィンによる透視を施行したところ下部食道の払張が 見られたすのの造影剂の流れは良好で嘔吐等も見られ なかったので経鼻胃管から初日は $5 \%$ ブドウ糖液，2 日目より母乳投与を始め徐々に投与量を増やしていっ た(図 5 )。術後32日目に経重胃管を抜去し直接哺乳を させて以後はさしたる合併症もなく徐々に体重の増加 も見られ初回術後51日目に退院となった（表 3 ）.

\section{考察}

新生児胃破裂は新生児の消化管穿孔の中では最も頻 度が高いが34)，成因については胃壁の解剖学的特異 性，周産期の低酸素やストレスに起因する胃壁の血流 低下，消化管の閉塞機転に伴 5 胃内圧の上昇説がある ものの大部分が不明である5). 発症する時期はほとん どが生後 2 ～ 5 日目であり，7 日目以降に発症する事 は稀で，破裂する 1 ～ 2 日前に前駆症状として哺乳力 減退, 非胆汁性嘔吐, 血性虽吐, 腹部膨満などが見ら れると言われている6). 破裂すれば高度の腹部膨満と 呼吸困難によるチフノーゼ，重症例ではショック状態 となる.X 線検查では, Saddle bag sign, foot ball sign と呼ばれる腹腔内の大量 free air 像, 腸管の下方圧排, 腹腔内液体眝留による鏡面像が見られる

本症例も生後 3 日目頃より腹部膨満をきたしすでに 破裂したと思われる生後 5 日目に高度の腹部膨満と呼 吸困難を起こして某産婦人科より当院小児科 NICU に運ばれて来た。胸腹部 X 線検查にて両側横隔膜下の 多量の free air 像, 胃泡の消失, 小腸ガス像の消失, 腹腔内眝留液による鏡面像を認めさらに腹水穿刺にて 黄色膿汁液を採取して上部消化管穿孔，特に胃破裂を 強く疑った，新生児胃破裂の死亡率は以前は70～80\% 
の高事であったが，新生児の術前術後の管理が進歩し

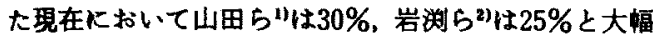
な改善を埌告している．とはい光新生児失患の中では 今な和高い死亡率と言わざるを得ない，予後を决定す る因子として大沢らクは，合併病变の有無，治療内容， 腹膜炎の程度を挙げているが最も影暗するのは腹膜炎 の辟度であると報告している。

さらに嗄膜奖の程度は術前授乳の有無，発症してか ら診断されて手街に至るまでの時間，破裂部の大きさ が溧く関与しており，郝前非授乳例は授乳例上り明ら にかに予後が良くまた当然早期に手術された症例，破 裂部の小さい症例の方が予啳良好で，授乳例に予後不 良例の多い理由をミルクが腹腔内で細菌の適当な培地 となるためとしている．授乳と腹水中の菌の検出につ いて岩溯ら ${ }^{21}$ 生，授乳例では12例中11例 $(91.7 \%)$ に菌 が换出されたのに对し，非授乳例では 8 例中 4 例 （50\%）にとどまり，死亡例に Kleb. Pneumoniae，E. coli 等のグラム陰性菌の発生が多く，生存例には staph. epidermidis の発生が多く見られたと報告して いる。.さらに血液培美陽性 6 例中 5 例 (83.3\%) 方死 亡し菌は腹水で見られたりのと同し傾向を示したと述 ベている。

術前検査上高度な Acidosis を示した症例, 白血球が 正常範用かむしろ低下していた症例，術前利尿の得ら れなかった症例も予後不良と言われている11999. 本例 でる高度な Acidosisを示し白血球数 眖水がありな

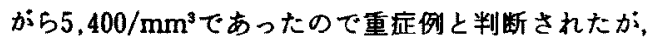
㫱前の充分量の輸㾋, フルブミン製剂，ドーバミン製 剤の投与によって利尿が得られ Acidosis ひメイロン にて改善されたので婜急手術に踏み切る事ができた。 胃破裂の部位は大多数の報告例が胃体上部大督側であ ク，その手術治療について加来ら ${ }^{61}$ は破裂部の胃壁の 境死片があれば切除し2 層〜3層で群合したと述べ， 木村 ${ }^{101}$ は䁈膜筋層断裂部。破裂孔と共に切除し 2 層 耗合を行ったと報告している。しかし山田ら゙は破裂 部胃壁の血行不良部分の切除，㓱縁の新鮮化恃出血量 を增し手術時間を延長させるだけで何の利点すないと 述へている，自駼例でる胃体上中部大警側の破裂部 位に対してDébridement はせずに 3 層赫合したが術 後挥合不全は見られなかった。術後管理について遠藤 ら"1は呼吸障害の見られた患者等対するレスビレー ターに上る積極的な呼吸管理，抗生剂の大量投与,トー ハミン副腎皮質ステロイド，シギタリス剤等による抗 ショック療法, 腎不全に対する利尿剤の投与, DIC 予

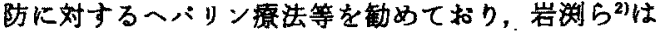
Protase inhibitorである FOY，ミラクリッド等が，細 菌性ショックk有效であったと述へてている。河野 ${ }^{12)}$, 土 田 ${ }^{13}$ は敗血症を起こした重症例に交換輸血が効を奏 した症例を報告している。

桔 語

生後 5 日目に新生児胃破裂を起こした症例に対して

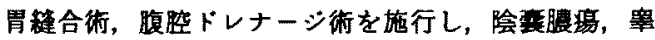
丸境死，䀴囲膿瘍を併発したるのの当院小児科 NICU における集中的な街前後の管理によって救命し得た 1 例を経験したので若干の文嘀的考察を加えて報告し た.

\section{文 献}

1）山田兑二, 角田昭夫，西 寿治他：新生児胃破裂の 術前，術中，術後管理，小児外科 $12 ： 969-975$ ， 1980

2）岩说 真，大沢義弘，八木 実他：敗血店，ショッ ク一胃破裂症例妾中心に一，日小外会誌 $25: 999$ $-1006,1989$

3）角田昭夫，武藤堚一：我国の新生児外科の現㫛，日 小外会誌 $15: 907-975,1979$

4）斉漛純夫：昭和 58 年度新生児外科の現㫛，日小外 会誌 $20: 1113-1120,1984$

5）植田 隆：新生児の消化管穿孔，胃と腰 6：423 $-428,1971$

6）加来后婎，広賴貫之，川駃英資他：新生児胃穿孔 10 例の梌討。㭂外会誌 9:633-639, 1973

7）大沢義弘，昖浦恵子，岩朔 真：新生児胃破糸の予 後因子と治療，腹部教急訩療の進步 $6: 489-493$ ， 1986

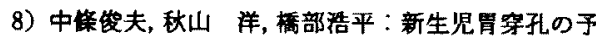
後を左右する因子の梌討，日小外会誌 $15 ； 215$, 1979

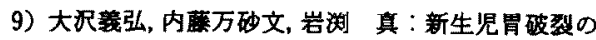

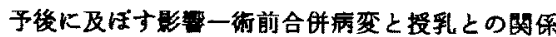
について一，日産媓新揚地方部会誌 $38: 12-15$, 1985

10)）木村 健，若山芳彦，津川 力：新生児胃破裂の 治痖，小児外科 $10: 525-530,1978$

11）遠藤昌夫：新生児胃破裂の治療一胃破裂症と endotoxin shock一，小児外科 $10: 531-538 ， 1978$

12）河野潜男：新生児外科的患に拈ける新生児敗血

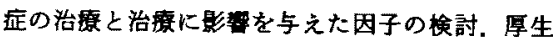

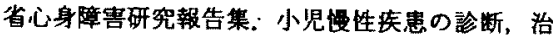
療，管理に関する研究玨，昭和 59 年研究業纊, p288 
$-290,1985$

13）土田嘉昭，本名敏郎，岩中 督：新生児消化管穿孔 の治㟟に阅する管理基準、愿生省心身障害研究報

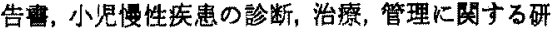
究班, 昭和 60 年度研究業績集、V 新生児外科疾患 に成する棕合的研究, p395-398, 1986

\section{A CASE OF INFANTILE IDIOPATHIC GASTRIC RUPTURE}

Shoji MATSUI, Hiroshi FUKUDA, Kyosuke OTA, Hirokazu ONO, Kasei HASHIMOTO,

Wataru FUIIMOTO and Akihito ISHIDA*

Department of Surgery and Pediatrics*, Kakogawa Municipal Hospital

Emergency operations including suture of the stomach and celiac drainage were performed for a 5-day-old male infant who developed idiopathic gastric rupture. E. coli was detected from the acites and blood, and the infant was diagnosed as general peritonitis associated with septicemia. The life of the baby could be saved by intensive postoperative management. On the 13 th postoperative day, inflammation with necrosis of the right spermatic cord and testis as well as perianal abscess occurred, which were sucessfully cured by incision of the scrotum with drainage for the abscess, right orchiectomy, and incision of perianal abscess with drainage. 